\title{
KARAKTERISTIK PERKEMBANGAN TAFSIR AL-QUR'AN PADA ABAD IX (Analisis Historis Metodologis)
}

\author{
Andi Miswar \\ Universitas Islam Negeri Alauddin Makassar \\ Email: Andimis04@gmail.com
}

\begin{abstract}
In the development of quranic interpretation, the IX century is known as the mutaakhhirin period. In this era interpretation shows fundamental change, for example the change from the form of $b i$ al-ma'tsur (riwayah) exagesis to the form of dirayah (al-ra'yu) exegesis, as it is practiced in jalalayn exagesis by jalaluddin almahally and jalaluddin al-sayuti that it is using ijmali or global method, and placing exegesis within it is global or general context. The exagesis book was published in that century is the interpretation of tafsir tanwir al-miqbas min tafsir Ibnu Abbas exegesis by al-fairuzabādi applies ijmali method such as tafsir $b i$ al-ma'tsur and tafsir al-Dür al-mansūr fi tafsir al-ma'tsūr by jalaluddin al-sayuti, which applying ijmali and muqāran, in the form of tafsir bi al-ma'tsur, the exagesis is classified as general exegesis. The tendency of exegesis mostly impluenced by their personal understanding, school of thought, and qualification of their knowledge.
\end{abstract}

Keyword: Methode, Exegesis, Development.

\begin{abstract}
Abstrak
Dalam Perkembangan tafsir al-Qur'an, abad IX dikenal dengan periode mutaakhhirin. Di era ini kegiatan penafsiran mengalami perkembangan yang cukup signifikan, misalnya dari bentuk tafsir bi al-ma'tsur (riwayah) ke bentuk tafsir dirayah (al-ra'yu) seperti yang terdapat dalam Tafsīr Jalalayn Oleh Jalaluddin al-Mahally dan Jalaluddin al-Syayuti yang menggunakan metode ijmāli atau global, serta memberikan gambaran penafsiran yang bercorak umum. Kemudian beberpa tafsir yang lahir pada masa tersebut, diantaranya, Tafsīr Tanwīr al-miqbās min tafsīr Ibnu Abbās oleh al-fairuzabādi menggunakan metode ijmāli dengan kategori bentuk tafsir bi al-Ma'tsūr, Dan Tafsīr al-Dūr al-Mantsūr fi tafsir al-ma'tsūr oleh Jalaluddin al-Sayūti disamping menggunakan metode muqāran juga ijmali, dengan bentuk tafsir bi al-ma'tsūr tafsir ini dikategorikan pula bercorak umum. Kecendrungan Mufassir dalam melakukan penafsiran kebanyakan dipengaruhi oleh pemahaman pribadi, mazhab, dan kwalifikasi keilmuan mereka.
\end{abstract}

Kata Kunci: Metode, Tafsir, Perkembangan. 


\section{A. Pendahuluan}

Meskipun Al-Qur'an sebagai sebuah kitab suci bagi umat Islam yang tidak diragukan kebenarannya, yang berisi petunjuk bagi orang-orang yang bertakwa, tetapi tidak berarti bahwa setiap orang akan memiliki kemampuan untuk memahami kandungannya. Karena itu, dengan keinginan dan semangat yang kuat untuk mengetahui maksud yang terkandung di dalam al-Qur'an dan kewajiban untuk mengamalkannya, maka muncul para ahli tafsir dengan karyanya masingmasing yang patut dihargai sebagai suatu khazanah keislaman yang tinggi.

Dengan memperhatikan dan membaca realitas sejarah pada abad ini, yang sarat dengan peperangan yang menyebabkan kehancuran. Sehingga perkembangan ilmu pengetahuan kurang mendapat respon dari penguasa pada saat itu. Karena yang menjadi fokus perhatian adalah bagaimana memperkuat militer untuk mempertahankan kekuasaan dan menaklukan dinasti yang ingin dikuasainya ketika itu. Mungkin ini salah satu faktor yang menyebabkan Syafiq A.Mughni memasukkan abad IX ini sebagai abad kegelapan.

Perkembangan ilmu pengetahuan pada abad ini diantaranya pada bidang filsafat dan sastra, tarekat dan tasawuf, dan termasuk karya tafsir. Dan karyakarya yang muncul masih didomonasi karya yang berbentuk ikhtisar dan syarh. Kegiatan penafsiran yang dilakukan oleh para ulama ketika itu tidak terpengaruh dengan kondisi kenegaraan sebagaimana telah disebutkan sebelumnya. namun mereka tetap fokus dengan masalah keagamaan.

Adapun kitab tafsir yang lahir pada abad IX ini yang terdeteksi melalui beberapa sumber dan literatur yang ada dan dianggap refresentatif untuk melihat perkembangan tafsir pada masa itu, dan setidakya memberikan kontribusi terhadap tafsir modern, yang dibuktikan bahwa karya tersebut masih menjadi salah satu rujukan ulama-ulama modern dalam berbagai masalah keagamaan, adalah Tafsir jalalain karya Jalaluddin Muhammad bin Ahmad bin al-Mahalliy asy-Syafi'i, al-Dur al-Mantsur fi tafsir al-ma'tsur, karya al-Hafidz Jalaluddin Abi al-Fadhil Abd bin Abi Bakar bin Muhammad al-Suyuti asy-Syafi'iy, Tanwirul Miqbas min tafsir ibn Abbas $(817 \mathrm{H})$ oleh Tahir Muhammad ibn Ya'qub al- 
Fairuzabadi, al-Jawahir al-Hasan fi tafsir al-Qur'an yang merupakan ikhtisar dari tafsir ibn Athiyah. Oleh Abu Zaid Abdu Rahman bin Muhammad bin Makhluf alSa'labi (w.876 H) . ${ }^{1}$

Ulama mutaqaddimin telah berusaha keras dalam menafsirkan ayat-ayat alQur'an dan telah menghasilkan kitab tafsir yang cukup lengkap. Keadaan seperti ini menjadikan sebagian kalangan ulama merasa puas, sehingga tidak banyak yang berusaha untuk melakukan penafsiran sendiri, hal ini berdampak pada kurangnya karya tafsir masa mutaakhhirin dibandingkan dengan produksi tafsir pada masa mutaqaddimin

Berkaitan dengan latar belakang tersebut di atas, maka dalam kajian ini penulis akan mengulas tentang bagaimana Karakteristik perkembangan tafsir pada abad IX dan bagaimana corak serta metode tafsir pada masa tersebut.

\section{B. Perkembangan Tafsir Pada Abad IX}

Karya tafsir yang lahir pada abad ini, seperti Tafsir Jalalayn, Tafsir Tanwīr al-Miqbās min tafsīr ibnu Abbas dan tafsir Jalalayn dan tafsir al-Dūr al-Mantsūr fì tafsīr al-Ma'tsūr, tidak ditemukan penggunaan riwayat israiliyat (yang dapat menimbulkan jebakan pada cerita-cerita mitos yang mengotori nilai keangungan ajaran Islam), ${ }^{2}$ seperti halnya tafsir yang lahir pada masa tabi'in dan tabi' tabi 'in.

Tafsir pada abad ke IX ini masih menganut sistem mushäfì, dimana penafsiran dilakukan dengan mengikuti tata urutan ayat dan surah seperti apa yang ada dalam mushaf usmani. Berkaitan dengan hal tersebut, mufassir seringkali diperhadapkan dengan kenyataan adanya ayat-ayat yang memiliki redaksi yang mirip dengan ayat lain yang kebetulan terdapat dalam beberapa surah. Seperti Tafsir Tanwīr al-Miqbās min tafsīr ibnu Abbas dan tafsir Jalalayn yang menggunakan metode ijmāli.

${ }^{1}$ Muhammad Husain al-Zahabi, Tafsir wa al-Mufassirun, Juz 1 (Cet.VI; Mesir: t.pt, 1416H/1990 M), h. 257-258. 2008), h. 48 .

${ }^{2}$ Abd Mustaqim, Pergeseran Epistemologi Tafsir ( Cet.I; Yogyakarta: Pustaka Pelajar, 
Keanekaragaman corak tafsir yang berkembang saat itu sejalan dengan keragaman disiplin ilmu yang berkembang saat itu yang menjadi minat mufassirnya, karena sebagian mufassir melakukan penafsiran al-Qur'an didominasi oleh kepentingan speliasisasi yang menjadi basis intelektual mereka, Sehingga muncullah apa yang kemudian disebut dengan tafsir fiqhi, tafsir $i$ 'tiq $\bar{a} d \bar{l}$, tafsir $s \bar{u} f i$, tafsir $i l m \bar{\imath}$ dan tafsir falsafi serta tafsir adab ijtimāiy. Adapun tafsir yang lahir pada abad ini, diantaranya adalah : Tafsīr Jalalayn Oleh Jalaluddin alMahally dan Jalaluddin al-Syayuti, Tafsìr Tanwīr al-miqbās min tafsìr Ibnu Abbās oleh al-fairuzabādi, Tafsìr al-Dūr al-Mantsūr fi tafsir al-ma'tsūr oleh Jalaluddi alSyayuti.

\section{Metode dan Corak Tafsir abad IX}

\section{Tafsir Jalalayn Oleh Jalaluddin al-Mahally dan Jalaluddin al- Syayuti (Corak Pemikiran Tafsirnya)}

Tafsir ini adalah karya Jalaluddin Muhammad bin Ahmad Muhammad bin Ibrahim al-Mahalliy . Ia lahir di mesir pada tahun $791 \mathrm{H}$ dan wafat pada tahun 876 H. Ia dikenal dengan sebutan al-Mahalliy yang dinisbahkan pada kampung kelahirannya yang terletak disebelah barat kota Kairo, tidak jauh dari sungai Nil. Kitab ini kemudian dilanjutkan dan diselesaikan oleh Jalaluddin al-Sayuthi.

Jalaluddin al-Sayuti, dengan nama lengkap Jalaluddin Abd Rahman Ibn Abi Bakr Ibn Muhammad Ibn Sabiq al-Din al-Khudairi al-Suyuti. Ia lahir pada tahun $849 \mathrm{H}$, dan Ia besar di Kairo dan belajar dari sejumlah ulama besar, diantaranya Jalaluddin Muhammad Ibn Ahmad Ibn Muhammad al-Mahalli, Syarf al-Din Ibn Yahya Ibn Muhammad al-Munawi, Taqy al-Din Ahmad Ibn Muhammad alSyumuni, dan sebagainya. ${ }^{3}$ Ia menguasai Ilmu bahasa Arab, Fiqh, hadis, tafsir, sejarah, usūl dan lain-lain.

Dalam menulis tafsir ini Jalaluddin al-Mahalliy memulai dari awal surah al-Kahfi sampai pada surah al-Nas. Lalu kemudian menafsirkan surah al-Fatihah, setelah beliau menyelesaikan al-fatihah, ia dipanggil menghadap ke yang maha

\footnotetext{
${ }^{3}$ Abd al-Qādir al-Arnāut, Taqdīmal-Tafsìr, Jalal al-Din Muhammad Ibn Ahmad Ibn Muhammad al-Mahalli wa Jalal Abd al-Rahman Ibn Aby Bakr al-Suyuti, al-Qur'an alKarim,Tafsir al-Imam al-Jalalayn ( Dimasyq: Dār Ibn Kasīr,1400 H.) h. 9.
} 
kuasa. Kemudian surah yang tersisa dilanjutkan oleh jalaluddin al-Suyuti, yaitu mulai dari surah al-Baqarah (2) sampai surah al-isra' (17). Dalam melanjutkan penyusunan Tafsir Jalalain, Jalaluddin al-Suyuti mengikuti metode yang ditempuh oleh Jalaluddin al-Mahalli. ${ }^{4}$ Sehingga hampir tidak ditemukan perbedaan antara keduanya kecuali beberapa hal .

Al-Mahalli dan al-Sayuti telah meletakkan kerangka khusus dalam menafsirkan ayat-ayat al-Qur'an : 1. Mengutip suatu ayat sampai selesai satu ayat kemudian disertai penjelasannya. 2.Analisa dalam tafsir ini terkadang berupa muradif dan penjelasan suatu makna lafadz tertentu dari ayat al-Qur'an. 3. Terkadang menggunakan penjelasan i'rab pada kosa kata tertentu dari ayat alQur'an. 4. Penafsirannya dapat diterima semua kalangan ulama, atau memilih yang paling kuat. 5. Mereka menggunakan bahasa yang singkat dalam penjelasannya. 6. Menghindari penjelasan yang panjang, bertele-tele, dan yang tidak disenangi oleh banyak orang. 7. Mereka tidak menafsirkan fawatih al-suwar (wallahu a'lam bissawab).

Dengan melihat aspek corak yang digunakan al-Mahalli dan al-Suyuti dalam tafsirnya, maka tafsir jalalayn dapat dikategorikan sebagai tafsir bi al-ra'yi yang menafsirkan ayat demi ayat dengan menggunakan hasil pemikiran ijtihad. Dengan demikian, sangat logis bila tafsir al-jalalyn dimasukkan dalam klasifikasi tafsir bi al-ra'y. Kemudian karena uraiannya yang begitu singkat, padat, serta tidak tampak gagasan atau konsep-konsep yang menonjol dari penafsirnya dan tidak didominasi oleh pemikiran-pemikiran tertentu melainkan mereka menafsirkan ayat-ayat al-Qur'an sesuai dengan kandungan maknanya. Disamping itu penafsiran ini dilakukan berdasarkan ijtihad dengan tidak mengabaikan qaidah bahasa, disamping itu sangat memperhatikan pendapat ulama para pendahulunya.

Karakteristik uraian Tafsir ini sangat singkat, dan jarang ditemukan perbedaan penafsiran. Adapun dari segi bentuk, banyak yang menilai bahwa ia

${ }^{4}$ Thameen Ushama, Methodologies of The Qur'aniq Exegisis diterjemahkan oleh Hasan Basri dan Amroeni dengan judul Metodologi Tafsir al-Qur'an : Kajian Kritis Obyektif dan Komprehensif (Cet, I; Jakarta : Riora Cita, 2000), h. 77. 
masuk dalam kelompok tafsir bi al-ra'yi, ${ }^{5}$ menurut Ahmad Izzan bahwa penafsirannya banyak dibangun di atas kaidah-kaidah dan uslub-uslub kebahasaan dalam memaknai dan memahami nash-nash al-Qur'an. ${ }^{6}$

Selanjutnya metode yang digunakan adalah metode ijmali atau global, yakni menafsirkan al-Qur'an secara singkat dan global, tanpa uraian panjang lebar . Mufassir dalam hal ini menafsirkan al-Qur'an secara sistematis dari awal hingga akhir. Dan menjelaskan arti dan maksud ayat dengan uraian singkat yang dapat menjelaskan sebatas artinya (ayat demi ayat dan surah demi surah) tanpa menyinggung hal-hal selain arti yang dikehendaki. Sehingga pembaca merasa bahwa uraian tafsirnya tidak jauh dari konteks dan gaya (uslub) bahasa al-Qur'an.

Sementara corak tafsir ini adalah termasuk corak umum, karena dengan memperhatikan dominasi pembahasannya tidak terfokus pada satu bidang .Namun didalamnya disinggung masalah figh, tasawuf maupun yang lain. Salah satu contoh penafsiran dalam kitab tafsir ini yang bercorak umum dapat dilihat pada surah al-Nisa / 4 (1) adalah sebagai berikut :

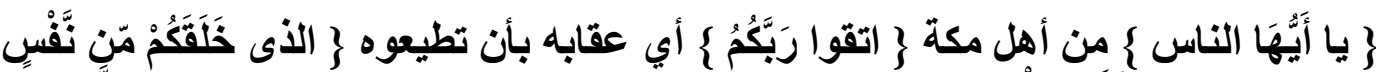

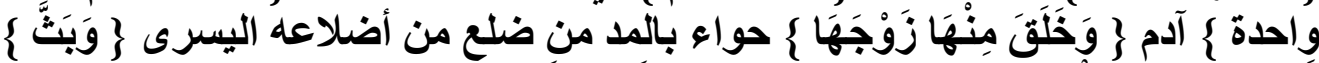

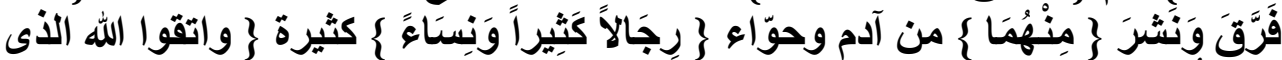

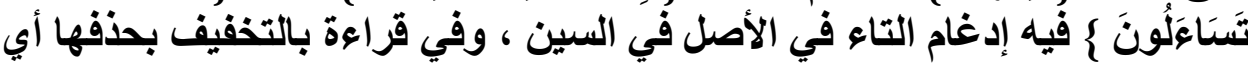

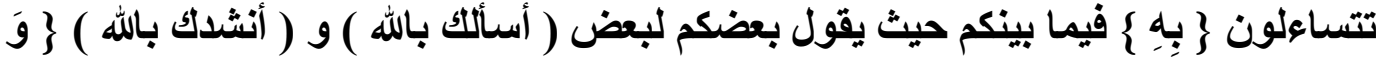

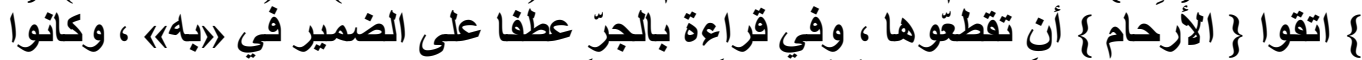

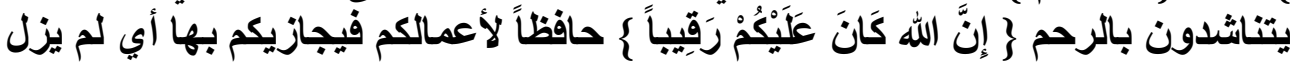
متصفا بذلك .

Contoh tersebut di atas menggambarkan penggunaan metode ijmali atau global yang mana uraiannya sangat singkat dan padat, sehingga tidak tampak gagasan, ide-ide atau konsep-konsep yang menonjol dari mufassir.

\section{Tafsir Tanwīr al-miqbās min tafs̄̄r Ibnu Abbās oleh al-fairuzabādi Corak Pemikiran Tafsirnya)}

${ }^{5}$ Nashruddin Baidan, Wasan baru ilmu tafsir (Cet.I; Yogyakarta: Pustaka Pelajar, 2005), h, lihat juga Ahmad Izzan, Metodologi Ilmu Tafsir (Cet.I; Bandung: Tafkkur-Humaniora-IKAPI, 207), h.75.

${ }^{6}$ Ahmad Izzan, Metodologi Ilmu Tafsir, h. 72. 
Tafsir ini adalah karya Majd al-Dīn Abu Tahir Muhammad ibn Ya'qub ibn Muhammad ibn Ibrahimal-Syairāzi al-Fairuzabādi. Lahir pada tahun 729 H di Kazrun. Ayahnya seorang ahli bahasa dan sastra di Syairaz. Ia telah menghafal alQur'an dan menggeluti literatur bahasa dan sastra ketika berumur tujuh tahun. Ia seorang imam dan ulama besar, pakar bahasa, sastra, hadisdan ilmu hadis. Selain itu, ia juga seorang sufi yang berbudi luhur yang menguasai sejarah.

Dalam catatan sejarah dikatakan bahwa sosok ulama sepeti al-Fairuzabādi memiliki wawasan dan pengetahuan yang luas. Ia banyak belajar dari ulamaulama besar dizamannya.Selain tercerahkan oleh buku-buku bacaan yang dikonsumsinya, kemampuan menghafal dan Ia tekun bergelut dengan banyak referensi.

Selanjutnya tentang Ibnu Abbas, Ia adalah seorang sahabat Nabi Muhammad saw. Yang ahli di bidang tafsir al-Qur'an, sehingga sangat beralasan jika ia digelar Tarjuman al-Qur'an atau penafsiral-Qur'an. Selain kedalamannya dalam ilmu tafsir, Ia juga dikenal sebagai peletak dasar ilmu-ilmu tafsir yang sampai saat ini masih tetap dirasakan, khususnya tentang makna kata-kata tertentu yang ada dalam al-Qur'an. ${ }^{7}$ Ibnu Abbas juga menguasai ilmu lainnya seperti ilmu bahasa, fiqh,syair, sejarah orang-orang arab dan ilmu hadis.

Riwayat-riwayat tentang penafsiran Ibnu Abbas kemudian disusun oleh Abu Thāhir ibn Ya'qub al-Fairuzabādi (penyusun kitab al-Muhīt). Ia berhasil menghimpun atau mengumpulkan dan melakukan sistematika terhadap tafsir yang dinisbahkan kepada ibnu Abbas ini diberi judul Tanwīr al-Miqbās min Tafsīr ibnu Abbās. Tafsir yang dinisbahkan kepada Ibnu Abbas itu sudah dicetak dan diterbitkan oleh penerbit Dār al-Fikr di Beirut dalam satu jilid.Namun sebagian naskah aslinya dalam tulisan tangan masih tersimpan baik di perpustakaan Hamidiyah di Istambul Turki.

Sistematika penyusunan kitab tafsir Tanwīr al-Miqbās min Tafsīr ibnu $A b b \bar{a} s$ ini, al-Fairuzabādi mengikuti susunan mushaf usmāni. Surah-surahnya terdiri atas 114 buah surah. Susunan surahnya dimulai dari surah pertama (al-

\footnotetext{
${ }^{7}$ Jalāl a-Dīn al-Sayūti, al-Itqān fì Ulūm al-Qur'an, Juz 2 (Beirut: Dār al-Fikr,1979), h.319.
} 
fatihah) sampai terakhir (surah al-Nas) sebagaimana sistematika yang telah ditempuh oleh banyak penafsir sebelumnya.

Sebelum al-Fairuzabādi memulai pembahasan pada setiap surah, Ia menjelaskan periodisasi turunnya ayat, jumlah ayat-ayatnya, jumlah kosa katanya, jumlah hurufnya, dan dijelaskan bahwa sanad ini berasal dari Ibnu Abbas. Hanya saja sanadnya tidak disebutkan secara lenngkap, sehingga banyak kalangan ulama yang mempertanyakan, dan meragukan validitasnya, bahkan ada berpendapat bahwa tidak semua hadis yang ditulis berasal dari Ibnu Abbas. ${ }^{8}$

Alfairuzabādi menafsirkan ayat-ayat al-Qur'an dengan uraian singkat dan global, tanpa menguraikan dengan uraian yang panjang lebar. Ia menjelaskan sebatas artinya tanpa menyinggung hal-hal selain arti yang dikehendaki.Dengan demikian penulis menilai bahwa metode yang digunakan adalah metode ijmāli. Ia menafsirkan ayat demi ayat, surah demi surah sesuai urutan dalam mushaf dalam kerangka uraian yang mudah dengan bahasa dan cara yang mudah dipahami oleh semua kalangan.

Dari segi corak tafsir, telah tergambar pada nama tafsir yaitu Tanwīr al Miqbās min tafsīr Ibnu Abbas, bahwa tafsir ini diambil dari tafsir Ibnu Abbas dan Ibnu Abbas adalah sahabat Nabi Muhammad saw. Dengan demikian, cukup beralasan jika tafsir ini dikategorikan sebagai tafsir bi al-Ma'tsūr. Alfairuzabādi memulai tafsirnya di setiap surah dengan basmalah, kemudian ia mengatakan bahwa tafsir ini berasal dari Ibnu Abbas. Corak dan metode tafsir ini memiliki persamaan dan perbedaan dengan Tafsīr al-Dūr al-Mantsūr fi tafsir al-ma'tsūr oleh Jalaluddin al-Sayūti yang juga menggunakan corak yang sama, sementara metode yang digunakan oleh Jalaluddin disamping menggunakan metode muqāran juga ijmali.

\section{Tafsir al-Dūr al-Mantsūr fi tafsir al-ma'tsūr oleh Jalaluddi al-Suyuti (} Corak Pemikiran Tafsirnya)

\footnotetext{
${ }^{8}$ Jamāl al-Banna, Tafsir al-Qur'an al-Karīm Baina al-Qudamā wa al-muhdisīn (al-Qāhirah: Dār al-Fikr al-Islami, 2003), h.95. 
Tafsir ini adalah karya al-Hafidz Jalaluddin Abi al-Fadhil Abd bin Abi Bakar bin Muhammad al-Suyuti asy-Syafi'iy ( 849-911/ 1445-1505). Kitab tersebut merupakan ikhtisar dari "Tarjuman al-Qur'an" Beliau juga telah mengarang kitab ensiklopedi yang berjudul Majma' al-Bahraini wa mathla' alBadrain. ${ }^{10}$

Dikalangan ulama modern ia dianggap telah banyak memberikan pengaruh terhadap perkembangan ilmu pengetahuan termasuk ilmu tafsir. Menurut beberapa sumber bahwa kitab-kitab karyanya mencapai 538 kitab, sebagia karangan asli dan sebagian berbentuk ikhtisar dan kumpulan-kumpulan tulisan. Dibidang ilmu tafsir sebanyak 73, hadis 205, musthalah hadis 32, fiqh 71, ushul fiqh, ushuluddin dan tasawuf 20, lughah, nahwu dan sharaf 66, al-ma'ani, bayan dan badi' 6, kitab yang dihimpun dari berbagai disiplin ilmu 80 kitab , tabaqat wa al-tarikh 30, dan al-jami' $30 .{ }^{11}$

Adapun tokoh yang menjadi sumber inspirasi yang berpengaruh dalam penulisan tafsir ini adalah Ibnu Jarir al-Tabariy, seorang tokoh yang terkenal pada abad III H. Pengarang kitab jami' al-Bayan fi Tafsir al-Qur'an. Hal ini diakui oleh al-Sayuti sendiri, dan ia menambahkan bahwa kitab Tafsir al-Tabariy adalah kitab yang telah disepakati oleh para ulama sebagai kitab yang sangat tinggi nilainya.

Mengenai karakteristik kitab tafsir al-Dur al-Mantsur fi tafsir al-ma'tsur adalah di dalamnya terdapat banyak riwayat-riwayat dari ulama salaf tanpa melakukan seleksi terhadap hadis yang dimuat, sehingga hadis shahih maupun dhaif terdapat di dalamnya. Bahkan cerita israiliyat banyak ditemukan di dalamnya.

${ }^{9}$ Muhammad Husain al-Zahabi, Tafsir wa al-Mufassirun, Juz 1 (Cet.VI; Mesir: t.pt, 1416H/1990 M), H. 261-262.

10 Muhammad bin Alawi al-Maliki al-Hasni, Zubdah al-itqan fi ulum al-Qur'an diterjemahkan oleh Rosihan Anwar dengan judul mutiara Ilmu-ilmu al-Qur'an: Intisari Kitab alItqan fi ulum al-Qur'an al-Sayuti (Cet. I: Bandung: CV. Pustaka Setia, 1999), h.416.

${ }^{11}$ Mani' Abd Halim Mahmud, Manhaj al-Mufassirin, diterjemahkan oleh Syahdianor dan Faisal Saleh dengan judul Metodologi Tafsir : Kajian Komprehensif Metode Para Ahli (Cet. I; Jakarta: PT.Raja Grafindo Persada, 2006 ), h. 126-128. 
Tafsir ini termasuk dalam bentuk tafsir bi al-Ma'tsur, karena ia banyak menggunakan riwayat. Ide dan gagasan mufassir hampir tidak ditemukan didalamnya. Hal ini diperkuat oleh beberapa literatur yang menyinggung bahwa tafsir ini tergolong tafsir bi al-Ma'tsur. ${ }^{12}$

Salah satu contoh petikan tafsir al-Dur al-Mantsur fi tafsir al-ma'tsur dalam surah al-Baqarah /2 (3) sebagai berikut :

$$
\text { قوله تعالى : الأين يؤمنون بالغيب ويقيمون الصلاة ومما رزقناهم ينفقون }
$$

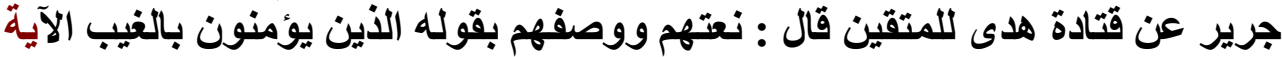

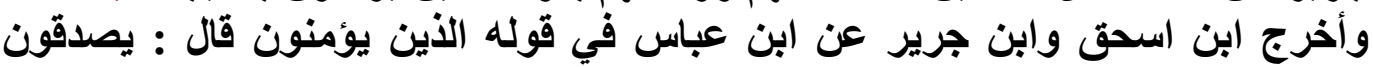

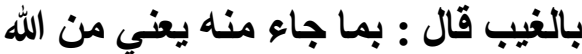

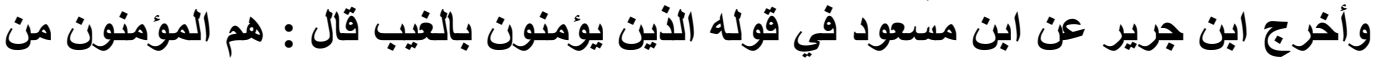
العرب قال : و الإيمان التصديق و الغيب ما غاب عن العباد من أمر الجنة والنار وما ذأنكر

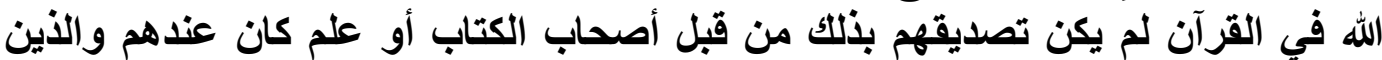

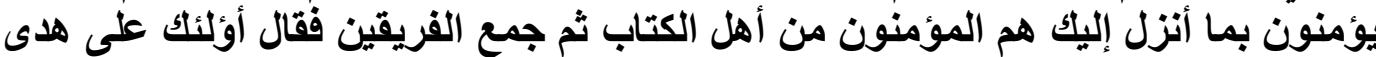

وأخرج ابن جريز وابن أبي حاتم عن أبي العالية في قوله الذين يؤمنون بالغيب قال : بالله

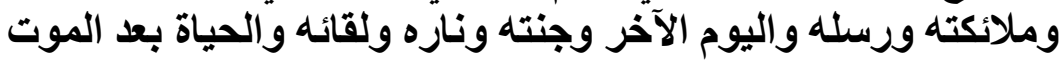

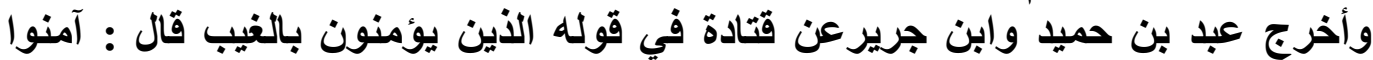

بالبعث بعد الموت والحساب والجنة والنار وصدقوا بموعود الله الذي وعد في هذا فئن القرآن

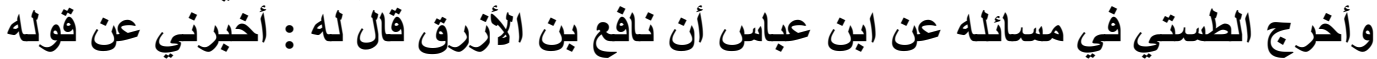

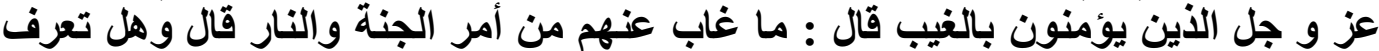

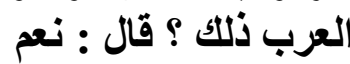

Dengan memperhatikan contoh penafsiran tersebut di atas, tergambar bahwa metode yang digunakan dalam penafsiran tersebut adalah membandingkan beberapa pendapat para ulama dan riwayat, di samping itu makna kosa kata tak lupuk dari cara kerja tafsir ini nampak bahwa metode yang digunakanadalah metode muqaran di samping juga ijmali.

Selanjutnya tentang corak Tafsir ini, karena penafsirannya banyak berdasarkan riwayat dan pendapat para ulama, tanpa kelihatan pemikirannya sendiri, serta tidak menonjolnya suatu bidang tertentu, maka tafsir ini dikategorikan bercorak umum.

12 Ismail .R.Al-Faruqi, The Cultural Atlas of Islam diterjemahkan oleh Ilyas Hasan ( Cet.III; t.tp: Mizan, 2001), h. 276. Lihat juga Mochtar Effendi, Ensiklopedi Agama dan Filsafat (Cet. I; t.tp: Percetakan Universitas Sriwijaya, 2001), h. 162. Lihat jua Departemen Agama RI, Ensiklopedia Islam di Indonesia (Jakarta: CV A nda Utama, 1992-1993), h. 76. 
Sebagai kesimpulan dari laporan baca ini bahwa situasi politik yang berkembang saat itu, tidak begitu berpengaruh bagi perkembangan tafsir ketika itu. Kedua tafsir yang penulis uraikan dianggap cukup mewakili tafsir abad ini.

\section{Penutup}

Kegiatan penafsiran ayat-ayat Al-Qur'an dari abad ke abad tidak pernah berhenti dan mengalami perkembangan yang cukup signifikan. Karya tafsir yang muncul Pada abad IX diantaranya, Tafsīr Jalalayn Oleh Jalaluddin al-Mahally dan Jalaluddin al-Syayuti, Tafsīr Tanwīr al-miqbās min tafsīr Ibnu Abbās oleh alfairuzabādi, Tafsīr al-Dūr al-Mantsūr fi tafsir al-ma 'tsūr oleh Jalaluddi al-Sayūti. Setiap produk penafsiran al-Qur'an tersebut memiliki corak dan karakteristik yang berbeda-beda berdasarkan perbedaan tingkat inteligensi Penulisnya, kecenderungan pribadi, latar belakang pendidikan, bahkan perkembangan ilmu pengetahuan dan kondisi masyarakat sosial yang mengitarinya.

Corak dan karakteristik dari setiap tafsir tersebut adalah, Tafsir Jalalayn menggunakan metode ijmāli atau global, karena Ia menafsirkan al-Qur'an secara global tanpa uraian panjang lebar. Kemudian dari segi bentuk termasuk dalam kelompok tafsir bi al-ra'yi, serta memberikan gambaran penafsiran yang bercorak umum, karena dengan memperhatikan dominasi pembahasannya yang tidak terfokus pada satu bidang.

Tafsìr Tanwīr al-miqbās min tafsīr Ibnu Abbās oleh al-fairuzabādi, menggunakan metode ijmāli dan dengan kategori bentuk tafsir bi al-Ma'tsūr. sementara Tafsīr al-Dūr al-Mantsūr fi tafsir al-ma'tsūr oleh Jalaluddin al-Sayūti, menggunakan metode muqāran dan ijmali, dengan bentuk tafsir bi al-ma'tsūr karena Ia banyak menggunakan riwayat dan pendapat para ulama, serta tidak menonjolkan suatu bidang tertentu, sehingga tafsir ini dikategorikan bercorak umum.

\section{DAFTAR PUSTAKA}

Abd Mustaqim, Pergeseran Epistemologi Tafsir, Cet.I; Yogyakarta: Pustaka Pelajar, 2008.

Ahmad Izzan, Metodologi Ilmu Tafsir, Cet.I; Bandung: Tafkkur-HumanioraIKAPI, 2007 
al-Arnāut, Abd al-Qādir, Taqīm al-Tafsīr, Jalal al-Din Muhammad Ibn Ahmad Ibn Muhammad al-Mahalli wa Jalal Abd al-Rahman Ibn Aby Bakr alSuyuti, al-Qur'an al-Karim, Tafsir al-Imam al-Jalalayn, Dimasyq: Dār Ibn Kasīr, $1400 \mathrm{H}$.

Departemen Agama RI, Ensiklopedia Islam di Indonesia, Jakarta: CV A nda Utama, 1992-1993.

Ismail .R.Al-Faruqi, The Cultural Atlas of Islam diterjemahkan oleh Ilyas Hasan, Cet.III; t.tp: Mizan, 2001.

Jamāl al-Banna, Tafsir al-Qur'an al-Karīm Baina al-Qudamā wa al-muhdisīn, alQāhirah: Dār al-Fikr al-Islami, 2003.

Mani' Abd Halim Mahmud, Manhaj al-Mufassirin, diterjemahkan oleh Syahdianor dan Faisal Saleh dengan judul Metodologi Tafsir : Kajian Komprehensif Metode Para Ahli, Cet. I; Jakarta: PT.Raja Grafindo Persada, 2006.

Mochtar Effendi, Ensiklopedi Agama dan Filsafat, Cet. I; t.tp: Percetakan Universitas Sriwijaya, 2001

Muhammad bin Alawi al-Maliki al-Hasni, Zubdah al-itqan fi ulum al-Qur'an diterjemahkan oleh Rosihan Anwar dengan judul mutiara Ilmu-ilmu alQur'an: Intisari Kitab al-Itqan fi ulum al-Qur'an al-Sayuti, Cet. I: Bandung: CV. Pustaka Setia, 1999.

Muhammad Husain al-Zahabi, Tafsir wa al-Mufassirun, Juz 1, Cet.VI; Mesir: t.pt, $1416 \mathrm{H} / 1990 \mathrm{M}$.

Nashruddin Baidan, Wasan baru ilmu tafsir ,Cet.I; Yogyakarta: Pustaka Pelajar, 2005.

Thameen Ushama, Methodologies of The Qur'aniq Exegisis diterjemahkan oleh Hasan Basri dan Amroeni dengan judul Metodologi Tafsir al-Qur'an : Kajian Kritis Obyektif dan Komprehensif ,Cet, I; Jakarta : Riora Cita, 2000. 